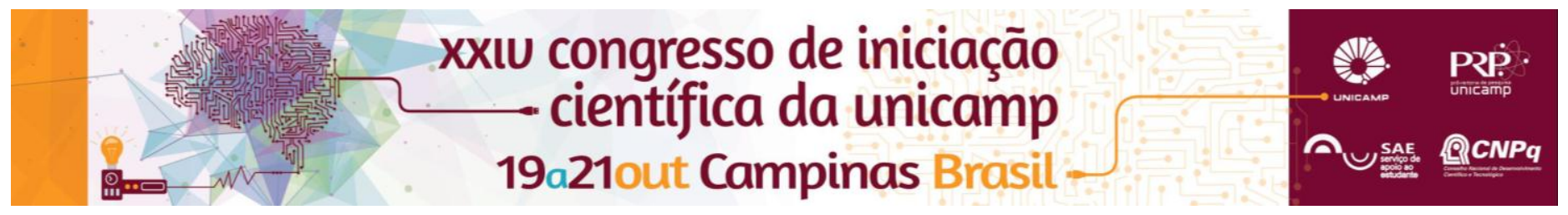

\title{
Estudo de parâmetros de interesse na produção de biossurfactante por Bacillus subtilis em biorreator aerado utilizando resíduo industrial contendo glicose
}

\author{
Lucas D. L. Costa * (IC), Juliana F. F. Secato (PG), Elias B. Tambourgi (PQ).
}

\begin{abstract}
Resumo
Os biossurfactantes são compostos tensoativos sintetizados por microrganismos quando cultivados em diferentes fontes de carbono e suas aplicações são em biorremediação, biodegradação, limpeza de reservatórios de óleos, recuperação terciária do petróleo, entre outras. Nos últimos anos, o interesse por biosurfactantes cresceu diante da preocupação com o meio ambiente e da legislação vigente para controle ambiental, buscando-se atualmente novas alternativas ao consumo de resíduos industriais por meio da produção de surfactantes naturais, compostos com baixa toxicidade e alta biodegradabilidade.Atualmente, os biosurfactantes apresentam altos custos de produçãom resultado da metodologia ineficiente do bioprocessamento, da baixa produtividade das cepas microbianas e da necessidade do uso de substratos de custo elevado. Assim, este projeto propõe o estudo de uma rota para a produção de biosurfactante por Bacillus subtilis, uma bactéria Gram positiva, não patogênica, variando-se fatores como quantidade de inóculo e aeração, utilizando como substrato resíduo industrial contendo glicose.
\end{abstract}

\section{Palavras-chave:}

Biossurfactante,Emulsificação, Tensão Superficial.

\section{Introdução}

Os biossurfactantes são compostos formados por moléculas com porções hidrofóbicas e hidrofílicas que através de seu acúmulo nas interfaces entre fases fluidas com diferentes graus de polaridade (água/óleo e óleo/água) reduzem as tensões superficiais e interfaciais aumentando a área superficial de compostos insolúveis, permitindo o aumento da mobilidade, biodisponibilidade e subsequente biodegradação. Atualmente, os biossurfactantes ainda não são capazes de competir economicamente no mercado com os compostos sintetizados quimicamente, devido aos altos custos de produção. Neste contexto, o principal objetivo deste trabalho é o estudo de parâmetros de interesse na produção de biossurfactantes por Bacillus subtilis. São eles: porcentagem de inóculo e aeração.

\section{Resultados e Discussão}

Os testes foram realizados em biorreatores aerados, com controle de $\mathrm{pH}$ e temperatura. $\mathrm{O}$ substrato utilizado foi o resíduo de uma indústria de balas, contendo alto teor de glicose. A melhor porcentagem de inóculo segundo os testes de emulsificação e tensão superficial foi fixada para a realização dos testes variando a entrada de ar, executados em sequência.

Tendo em vista a variação de tensão superficial foi possível encontrar uma relação de crescimento do potencial do biossurfactante como agente redutor de tensão à medida que se aumenta a porcentagem de inóculo, assim, melhores resultados foram encontrados com $10 \%$ de inóculo, valor máximo testado. Em relação à aeração, foi possível constatar que um constante aumento no valor de oxigênio no biorreator reduz a queda nos valores de tensão superficial, o que é especialmente constatado pelos valores encontrados nos testes com 1.5 $\mathrm{L}_{\text {air }} \cdot \mathrm{min}^{-1}$ e $2 \mathrm{~L}_{\text {air }} \cdot \mathrm{min}^{-1}$. O valor ótimo encontrado para a relação redução de tensão superficial e aeração foi de 1 $\mathrm{L}_{\text {air }} \cdot \mathrm{min}^{-1}$.

Na análise do inóculo e seu impacto no índice de emulsificação do biossurfactante produzido foi possível constatar que os valores ótimos foram obtidos com $7.5 \%$ e
$10 \%$ de inóculo. Para a variável aeração, notou-se uma queda considerada da emulsificação à medida que se aumentava a vazão de ar para o biorreator a partir do valor ótimo obtido, $1 \mathrm{~L}_{\mathrm{air}} \cdot \mathrm{min}^{-1}$. Desse modo, percebe-se que a vazão de $1 \mathrm{~L}_{\text {air }} \mathrm{min}^{-1} \mathrm{e}$ inóculo em $10 \%$ proporcionou excelentes resultados nos testes realizados, tanto para emulsificação como para redução de tensão superficial, como citado anteriormente. Para encerrar as observações frente ao índice de emulsificação é importante citar a grande capacidade emulsificante do biossurfactante produzido para óleo de motor, mostrando um possível direcionamento dos esforços para se estabelecer essa via de produção para tensoativos voltados a biorremediação de áreas contaminadas por hidrocarbonetos.

\section{Conclusões}

Conclui-se que a utilização da bactéria Bacillus subtilis para produção de biossurfactante é eficiente, tendo em vista o custo-benefício relacionado à fácil manutenção da cepa bacteriana, ao farto tipo de resíduo utilizado e resultados de emulsificação de hidrocarbonetos e redução de tensão superficial encontrados com o tensoativo produzido, sendo assim, merece contínuo estudo para intensificar o potencial do produto, e assim, consolidar-se como alternativa eficaz e sustentável frente aos seus semelhantes sintéticos que atualmente são majoritários no mercado.

\section{Agradecimentos Cof}

\footnotetext{
${ }^{1}$ Banat, I. M., 1995, "Biosurfactants production and possible uses in microbial enhanced oil recovery and oil pollution remediation: a review", Bioresource Technology 51, pp. 1-12.

${ }^{2}$ Cameotra, S. S., Makkar, R. S. Synthesis of biosurfactants in extreme conditions. Applied microbiology and Biotechnology, v. 50, p. 520-529, 1998 DOI: $10.1007 / \mathrm{s} 002530051329$.
} 